\title{
Atıksu Arıtma Tesislerinde Arıtma Çamurları ve Bertaraf Uygulamaları
}

\author{
Mert Yüksekdağ $\breve{1}^{1}$ Semir Gökpınar², Bekir Yelmen³ \\ ${ }^{1}$ İskenderun Teknik Üniv. Mühendislik ve Fen Bilimleri Enstitüsü, İskenderun, Hatay, Türkiye (ORCID: 0000-0002-2419-9021) \\ 2 İskenderun Teknik Üniv. Mühendislik ve Fen Bilimleri Fakültesi, Makine Mühendisliği Bölümü, , İskenderun, Hatay Türkiye (ORCID: 0000-0003- \\ 1509-6036) \\ ${ }^{3}$ Adana Büyükşehir Belediyesi ASKİ Genel Müdürlüğü, Adana, Türkiye (ORCID: 0000-0001-7655-530X)
}

(İlk Geliş Tarihi 6 Şubat 2020 ve Kabul Tarihi 31 Mart 2020)

(DOI: $10.31590 /$ ejosat.699952)

ATIF/REFERENCE: Yüksekdağ, M., Gökpınar, S. \& Yelmen, B. (2020). Atıksu Arıtma Tesislerinde Arıtma Çamurları ve Bertaraf Uygulamaları. Avrupa Bilim ve Teknoloji Dergisi, (18), 895-904.

\section{$\ddot{O} z$}

Atıksu arıtma tesislerinden (AAT) nihai çamurun yok edilmesi AAT lerinin başlıca sorunları olup Avrupa Atıksu Standartları Mevzuatında belirtilen hususlar doğrultusunda, çamurun içerisindeki patojen, organiklerin \% 75 'inin bertaraf edilmesi zorunludur. AAT lerinden nihai çamur ek tesisler yapılarak, yok edilerek elektrik enerjisi elde edilebilir. Bu çalışmada AAT lerinden nihai çamurun yok edilmesi, AAT leri açısından uygulanabilir yöntemler, buna bağlı örnekler ve bir tesisin yıllık proses değerleri incelenmiştir.

Anahtar Kelimeler: Atıksu arıtma tesisi, Çamur bertaraf yöntemleri, Biyogaz, Ceyhan

\begin{abstract}
The destruction of the final sludge from the wastewater treatment plants (WWTP) is the main problems of WWTPs. According to the European Waste Water Standards Legislation, 75\% of the pathogens and organics in the sludge must be disposed of. Electrical energy can be obtained by destroying the final sludge from the WWTPs by making additional facilities. In this study, the destruction of the final sludge from the WWTPs, applicable methods in terms of WWTPs, related examples and the annual process values of a facility are examined.
\end{abstract}

Keywords: Wastewater treatment plant, Sludge disposal methods, Biogas, Ceyhan

\section{Giriş}

İnsan nüfusundaki hızlı artış beraberinde artan bir tüketim trendine neden olmaktadır. Artan bu tüketim trendi üretim ile direkt olarak orantılı olup, tüm bu üretim ve tüketim proseslerinde beraberinde bertaraf edilmesi gereken devasa atıkları getirmektedir. Atıkların bertaraf edilmesi için yaygın olarak kullanılan atık su arıtma sistemleri, kirletilmiş suların toplama alanlarında kullanılan ve bu alanda suyun kirleticilerden arıtılmasını sağlayan sistemlerdir.

Günümüz de atık su arıtma tesislerinde (AAT) çamur yönetimi teknik ve ekolojik uygulamalar açısından çözülmesi gereken problemlerin başlıcalarındandır. Atıksuların arıtılmasında biyolojik proses önemli bir husus olmasına rağmen çıkan arıtma çamuru AAT'lerinde istenmeyen ve çözüm bekleyen bir problemdir. AAT'lerinin analizi ve iyileştirilmesi üzerine birçok çalışma mevcuttur. Buonocore ve ark. (2018) yapmış oldukları çalışmada güney İtalya'da bulunan bir atık su arıtma tesisindeki; atık su ve çamurun bertarafı için farklı senaryolar geliştirmişlerdir. Dahası, bu senaryolar sonucunda elde edilen veriler baz alınarak sistemlerin çevresel etkilerini karşılaştırmak için yaşam döngüsü değerlendirmesi metodunu sistemlere uygulamışlardır [1]. 
Molinos-Senante ve ark. (2018), atıksu arıtma teknolojileri için enerji yoğunluğunu modellemişlerdir. Çalışma kapsamında 305 farklı AAT için modelleme yapılmış olup, çalışma sonucunda kirletici temizleme verimliliğin AAT sistemleri üzerinde düşük etkilerinin olduğunu görmüşlerdir [2].

Çamurların bertaraf edilmesi hususunda uzun yıllardır birçok bilimsel çalışma ve araştırma gerçekleştirilmiştir.[3]. Ancak yapılan çalışmaların çoğunda enerji verimliliği arka planda tutulmuş, bu konuda verimliliğe dayalı bir tesis neredeyse hiç planlanmamıştır [4]. AAT lerde geri kazanım ile enerji üretilmektedir. Fakat tüketilen enerjinin tamamının üretildiği bir tesis neredeyse mevcut değildir [5]. Ayrıca yapılan bir başka çalışmada dünyada ve Türkiye'de enerji görünümünün genel değerlendirilmesi yapılmış olup, sonuçları aktarılmıştır. [6]

Gelişmiş bazı ülkelerde AAT'lerinden çıkan arıtma çamurlarının düzenli depolama yapılarak bertaraf edilmesi, ülke çevre yönetmelikleri açısından sakıncalıdır. Yeni yönetmeliklere göre çıkan çamur önce kurutulmalı daha sonra yakılma sonucu elde edilen küllerin sızdırmazlığı sağlanan uygun depolarda muhafaza edilmesi öngörülmektedir.

Tesislerden çıkan çamurun değerlendirilmesi ve farklı sektörlerde kullanılmasına yönelik çalışmalar mevcuttur [7]. Örneğin çamurun gübre olarak kullanılabilmesi [8], veya çamurun bir 1sıl enerji kaynağı olarak kullanılabileceği de görülmüştür [9].

Çamur bertaraf işlemi, arıtma tesislerindeki başlıca maliyet unsurlarından birisidir. Çünkü bir arıtma tesisinde çamur bertaraf yöntemleri tesisin toplam yapım maliyetinin \%20-\%30 unu, işletme maliyetinin ise \%50-\%70 lik bir kısmı çamur bertaraf yöntemlerine harcanmaktadır [10]. Bu bağlamda ele aldığımızda yapılan çalışmaların büyük bir bölümü aslında bu maliyeti düşürmeye veya faydalı bir şekilde kullanmaya yöneliktir. Bertaraf maliyetlerinin yüksek olmasına karşın, birçok ekonomik bertaraf yöntemleri de bulunmaktadır [11]

Atıklar işlenerek çevre sorunlarının çözünebilirliğinin yanı sıra, ülke ekonomisine de fayda sağlamaktadır. Örneğin doğanın ve atmosferin korunması ve verilen zararların minimize edilmesi için biyogaz eldesi organik atıklarda en uygun geri kazanım yöntemi olmakla birlikte; biyogaz üretimi ekonomiye önemli ölçüde kar sağladığı için uygun ve faydalı bir yöntemdir [12].

Liu ve ark. (2018) yapmış oldukları çalışmada seri kesikli biyogaz reaktörüne manyetik toz eklenmesinin reaktör performansı ve mikrobiyolojik topluluk üzerindeki etkisini araştırmışlardır. Çalışma sonucunda manyetik aktive edilmiş çamur sekanslı parti reaktörünün geleneksel seri kesikli biyogaz reaktöründen daha yüksek amonyak azotu ve kimyasal oksijen ihtiyacı giderim verimine sahip olduğunu göstermiştir [13].

Bu çalışmada Ceyhan atıksu arıtma tesisinin 2017 yılı arıtma tesisi kapasitesi, biyogaz üretimi, Biyogazdan enerji üretimi ve yıllık enerji tüketimini karşılaşma oranları incelenmiştir.

\section{Atıksu}

Sıvı veya başka bir ifade ile suyun taşıyabildiği evsel, endüstriyel nitelikli atıklar ile yüzey sularının, yeraltı sularının ve yağışların karışımına Atıksu denilmektedir. Daha farklı bir anlatım ile bir topluluğun ihtiyaçları sonucunda meydana gelen kullanılmış su atıksu olarak tanımlanmaktadır [14].

İçeriğinde kompleks organik madde içeren organizmalar mikrobiyolojik etmenler ile bozunmaya uğrayabilir. Örneğin kanalizasyon suyu. Sınıflandırmada atıksular bozunabilir kirletici olarak tasniflendirilmiştir [15] .

Atıksular evsel, endüstriyel ve kentsel atıksular olmak üzere 3 e ayrılır.

- EVSEL ATIKSULAR: Günlük yaşamın idame ettirildiği ev gibi yerleşim alanları, insanların toplu olarak bulunduğu hastane, okul ve otel vb. alanlardan kaynaklı atıksulardır [16].

- ENDÜSTRİYEL ATIKSULAR: Yağmur suları, evsel atık sular dışında endüstriyel veya ticari faaliyet yürütülen alanlardan kaynaklı atıksulara denilmektedir [16].

- KENTSEL ATIKSULAR: Kentsel atıksu ifadesi endüstriyel atıksu ve/veya yağmur suyunun karışımı ile oluşan atıksuya denilir.

\section{Atıksu Aritımı}

Fiziksel, kimyasal ve biyolojik işlemler vasıtasıyla değişik kullanımlar neticesinde bakteriyolojik, fiziksel ve kimyasal vasıflarını yitirmiş atıksuların bu özelliklerinin tamamının veya bir kısmının doğaya boşaldıkları alıcı ortam şartlarını değiştirmeden kazandırma yöntemlerini kapsar [16].

\subsection{Atıksu Arıtma Yöntemleri}

- FİIKSEL ARITMA: Farklı boyut ve ebatlarda ki yüzebilen çökebilen katı cisimlerin çözünmüş halde ki organik/inorganik madde ve gazların atıksudan uzaklaştırılması koşuluyla atıksuya uygulanan işlemlere denilmektedir.

- KİMYASAL ARITMA: Çeşitli kimyasal tepkimeler yardımıyla atıksu içerisinde kirletici etmenlere sebep olan çözünmüş, askıda veya kolloidal maddelerin giderimini sağlamak adına uygulanan yöntemlerdir. 
- BiYYOLOJIKK ARITMA: Atık suyun içerisinde bulunan mikroorganizmaların organik ve kısmen de anorganik kirleticileri enerji ve besin kaynağı adlederek atıksudan uzaklaştırma metoduna dayanan arıtma yöntemidir.

- İLERI ARITMA: Bileşenleri biyolojik yöntemler ile kolayca ayrışamayan organik maddeleri, ağır metalleri ve toksik maddeleri fiziko kimyasal yöntemleri içine alan ileri düzeyde arıtmaya verilen addır.

\section{Biyogaz}

Organik atıkların oksijensiz ortamda mikrobiyolojik flora ve bakterilerin etkisi ile kullanılabilir gaza dönüşümüyle meydana gelen gaza biyogaz adı verilir. Metan gazı ve karbondioksit organik maddelerin parçalanması sonucu oluşmaktadır. Biyogazın üretilme işlemi temel olarak organik yapının parçalanma ve ayrıştırılmasına dayandığı için hayvansal gübreler, bitkisel atıklar, endüstriyel atıklar temel madde olarak kullanılabilmektedir [17].

\section{Arıtma Çamurları}

AAT lerinden çıkan çamur; kokulu, yarı katı ve sıvı halde ki formlar "arıtım çamurları" olarak isimlendirilir. Nihai çamurların hacimlerinin büyük olmasının önemli sebebi; çamurun içerisinde ki Kuru Katı madde miktarının az, su miktarının ise fazla olmasıdır. AAT lerinden çıkan çamur arıtma proseslerine bağlı olmakla birlikte uygulanan tekniklerin farklılığına göre genel olarak \%5 - \%12 aralığında kuru katı madde içerir [18].

Arıtma sonucu çıkan çamurun bertaraf sebebi; çamurun kokuşma ve bozulmaya yatkın olmasıdır. AAT lerinden çıkan arıtma çamur yükü ve özellikleri atıksuyun bileşimine, atıksuyun arıtılmasında kullanılan arıtma tekniğine bağlıdır [19]. Çamur tiplerini oluşturan 3 ana çamur tipi mevcuttur. Bunlar; Ön çökeltme çamurları, kimyasal çamurlar ve biyolojik çamurlardır. Arıtma işlemlerinde kullanılan aktif çamur içerisinde ki mikroorganizma yükü gerekli miktarı aştı̆ında fazla miktarın sistemden uzaklaştırılması gerekir ve 'Atık Aktif Çamuru 'olarak adlandırılır ve arıtma tesisleri için önemli sorun teşkil etmektedir.

Biyolojik arıtma sistemlerinde ön çökeltim depolarından çekilen çamurların organik madde içeriği yüksek olurken, son çökeltim depolarından çıkan çamurların ise, aktif çamur tankında gelişen biyolojik kütleden kaynaklı olarak organik madde miktarı daha azdır [20].

\section{1. Çamur Bertaraf Yöntemleri}

Stabilizasyon: Arıtma sonrası elde edilen çamurun barındırdığı patojenlerin azaltılması ve buna bağlı olarak ortaya çıkan kokunun minimuma düşürülmesi, ayrıca; çürüme, bozunma gibi sorunların da giderilmesi için uygulanan bir çamur bertaraf yöntemidir. Belirttiğimiz bu bozunma, çürüme ve koku oluşumunu gidermek için eklediğimiz kimyasalların oluşturduğu çevresel koşullar, mikro organizmaların üreme ve büyümesini engelleyerek stabilizasyon çalışmasına fayda sağlamaktadır. Stabilizasyon yöntemlerinin başlıcaları; kireçle stabilizasyon, kompostlaştırma, havalı ve havasız çürütmedir.

AAT den çıkan çamurların stabilizasyonu 3 ana başlık altında incelenebilir. Bunlar Kimyasal, Biyolojik ve Termal yöntemlerdir. Dezenfeksiyon uygulanabilirliği açısından stabilizasyon uygulamaları incelendiğinde bazı ham arıtma çamurları dezenfekte olabilirken bazılarının dezenfeksiyonu tam olarak gerçekleştirilememektedir [21]. AAT lerden çıkan çamurların istenilen kurulukta olması için çok iyi stabilize edilmesi gereklidir [19]. Çamur stabilizasyonunun gerçekleşmesi; temel patojenlerin giderilmesi, istenmeyen koku ve kokuşmanın önlenmesi açısından gereklidir [22].

Çamur stabilizasyonu hacim azaltılmasının yanı sıra gaz üretimi için etkilidir. Stabilize olan arıtma çamurları; yeraltı suyu kalitesi, bitki örtüsü, toprak ıslahı üzerine olumsuz bir etki yaratmadığı gibi istenildiğinde ekolojik bakımdan güvenli olarak kullanılabilmektedir [23].

Şartlandırma: Bu yöntem, çamurun su bırakabilme yetisinin artırılması işlemi olarak tanımlanmaktadır. Mekanik yoğunlaştırma, çamur susuzlaştırmanın önemli bir parçası olan şartlandırma, 1sıtma, eritme, katılaştırma gibi fiziksel yöntemlerle veya organik-inorganik kimyasallar, çamur yakma firınlarından çıan küllerin kullanılmasıyla desteklenerek tatbik edilebilir. Çamur susuzlaştırmayı daha uygun hale getirmek için geliştirilmiş bir prosestir. Kimyasal şartlandırma ve $1 S 1$ arıtımı bu proses için en çok kullanılan yöntemlerdir.

Yoğunlaştırma: Çamurun içerdiği suyun uzaklaştırılarak, katı madde yoğunluğunun arttırılmasını, bunun sonucunda çamurun hacminin azalmasını sağlayan bir prosestir. Yoğunlaştırma işleminden sonra çamur akışkanlık özelliğini kaybetmemektedir.

AAT lerinde çamur yoğunlaştırma sistemlerinin kullanılmasının başlıca sebepleri; Yüksek çamur konsantrasyonu eldesi, daha az hacim ile daha ekonomik çürütücü deposu elde etmektir. Katı madde konsantrasyonu yoğunlaştırma ile yirmi beş katına çıkarılabilir.

Susuzlaştırma: $\mathrm{Bu}$ işlem, çamurun içerdiği nem oranının düşülmesi için uygulanan fiziksel bir yöntemdir. Bu işlem sonucunda hacimde ciddi bir azalma oluşurken aynı zamanda çamur kekinin kolay taşınabilirliği ve kekin kokusuz ve kokuşmaya elverişsiz olarak meydana gelmesine yardımcı olmaktadır. 
AAT lerinden çıkan çamurun bertaraf edilmesi için sıvı halden katı hale dönüştürülmesi gerekmektedir. Yoğunlaştırma sonucu çıkan çamur susuzlaştırma işlemine tabidir.

Yakma: Çamur içerisindeki yanmaya elverişli maddelerin ekzotermik biçimde oksidasyonuna denilmektedir. Su içeriği azaltılmış olan çamur, oksijen içeren bir ortamda $420-500{ }^{\circ} \mathrm{C}$ derecede tutuşabilir. Organik katıların tamamının yanması ise minimum $760-820^{\circ} \mathrm{C}$ derece sıcaklıkta gerçekleşmektedir.

Yakma işlemi sonucunda katı atıklar kütlesel olarak \%75, hacimsel olarak ise \%90 azalma kaydedilir [24].

AAT lerinden çıkan çamurlar yakılarak bertaraf edilir. Yakma sonucunda ortaya çıkan küller asfalt altı dolgu maddesi, kimya sanayisinde ve son y1llarda fosfor eldesinde kullanılabilmektedir.

Düzenli depolama: Belirlenen bir alanda arıtma çamurlarının tek olarak kabul edildiği (monolitik) ya da kentsel katı atıklarla beraberce depo edildiği uygulamalardır.

$\mathrm{Bu}$ depolama çeşidinde toprak kirliliğine neden olmaması için; depo yapılacak alan ekolojik bakımdan önem arz etmektedir. Ayrıca düzenli depolamadı en önemli husus, çamurun suyunun doğal veya mekanik yöntemlerle alındıktan sonra depolanmasıdır. Bu sayede çevreye vereceği zarar minimize edilmiş olur [25]. Düzenli depolama yöntemi, uygulanabilirlik açısından zor olmayan ve ekonomik bir yöntemdir. Atıksu arıtma tesisi akış şeması şekil 1'de verilmiştir [26].

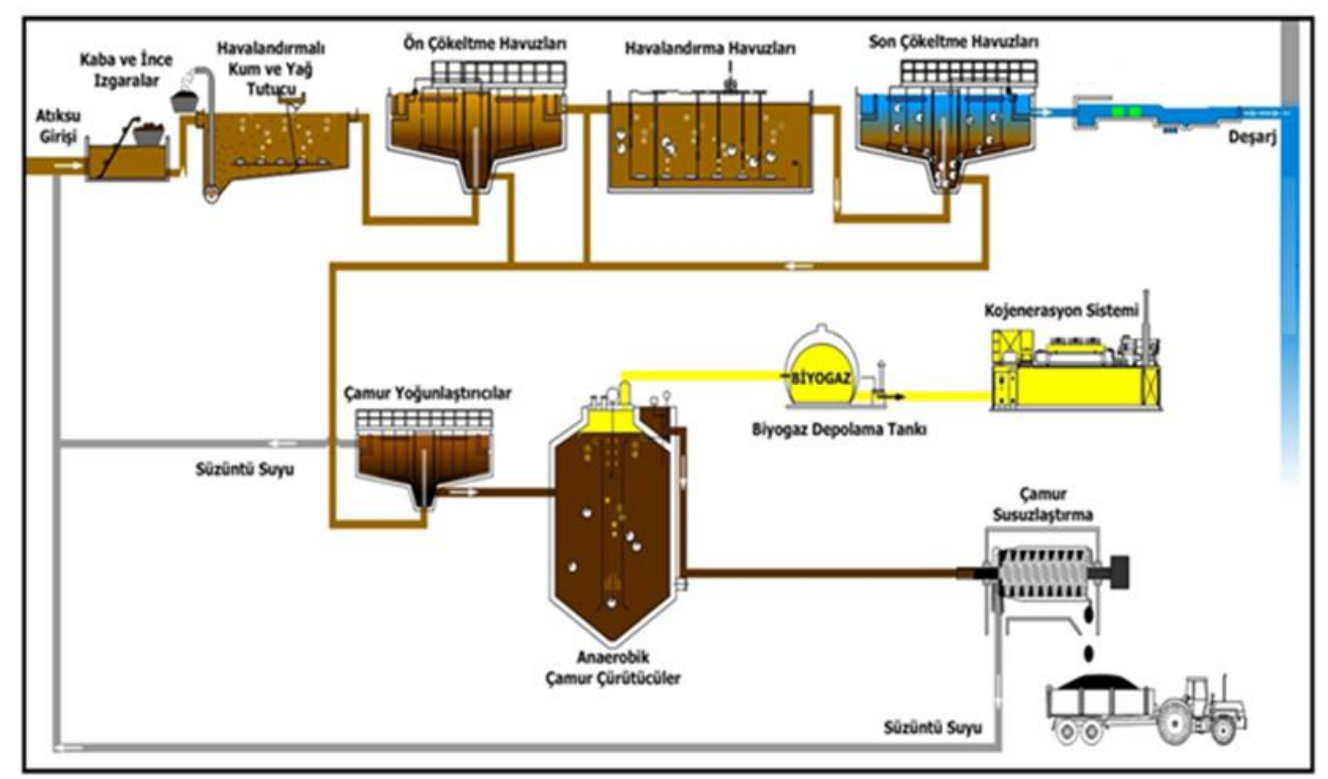

Şekil 1. Atıksu Arıtma Tesisi Akış Şeması [26]

Şekil 1. de görüldüğü üzere; Ceyhan Atıksu Arıtma Tesisine gelen evsel atık sular ilk olarak mekanik ön arıtmanın ilk ünitesi olan kaba 1zgaralara gelir. Bu ünitede $20 \mathrm{~mm}$ den büyük giriş pompalarına zarar verebilecek katı maddeler ayrılır. Atıksu daha sonra terfi pompaları vasıtası ile $7.5 \mathrm{~m}$ yükseltilerek ince 1zgara ünitesine gelir.5 mm den büyük pislikler perfore ızgaralar tarafından tutulur ve ayrıştırılır. Kaba ve ince 1zgaralardan geçemeyen atıklar ise taşıyıcı bantlar vasıtası ile çöp konteynerine dökülür. İnce ızgaralardan geçen atıksu bu üniteden sonra kum ve yağ ayırım havuzuna gelir. Bu ünitede suya yüksek basınçta hava üflenir ve kaba, ince pisliği alınmış atıksuyun bu havuzlarda yağ ve kumu alınır, ayrıştırılır. Daha sonra bu üniteden çıkan atıksu ön çökeltim havuzlarına gelir. Burada çöktürme işlemine tabi tutulur. Yerçekimi vasıtasıyla atıksu içerisinde bulunan kuru katı maddeler çökeltilir. Bu çökeltim neticesinde sıyırıcıların çamur haznelerinde biriktirmesi ile oluşan çamur pompalar vasıtası ile ön çamur yoğunlaştırıcıya pompalanır. Ön çökeltim havuzlarından geçen atıksu havalandırma havuzlarının geri devri ile birleşerek biyolojik arıtmanın başladığı ilk yer olan havalandırma havuzlarına gelir. Havalandırma havuzu oksijensiz ve oksijenli olmak üzere iki bölümden oluşmaktadır. Bu havuzlarda kirlilik olarak kabul edilen amonyum, karbon, fosfor, biyolojik oksijen ihtiyacı (BOI), kimyasal oksijen ihtiyacı (KOİ), askıda katı madde (AKM) gibi maddelerin giderimi yapılır. Buradan yoluna devam eden atıksu son çöktürme havuzlarına gelir. Yerçekimi etkisiyle nihai son çöktürme işlemi gerçekleştirilir. Daha sonra atıksu dağıtım yapısına gelir ve buradan da servis suyu istasyonuna gider. Oluşan çamur ise artan çamur ve geri devir pompa istasyonlarına gelir. Artan çamur pompaları çamuru, çamur yoğunlaştırıcıya pompalarken, geri devir pompaları ise biyolojik çeşitliliği var edebilmek ve aşılama yapabilmek adına ön çökeltimden gelen atıksu ile birleşmek üzere havalandırma havuzu önüne pompalanır. Ön çökeltim çamur yoğunlaştırıcı ve son çökeltim çamur yoğunlaştırıcıdan gelen çamurlar digestera (çamur çürütücüye) gönderilir. Çamur digestera girmeden önce 1sıtıcılar (eşanjörler ) vasıtası ile digester içerisinde çamurun istenilen sıcaklık değerinde olabilmesi adına 1sıtılır. Çürütücülerden biogaz eldesi yapılıp gazın CHP motorlarında yakılabilir hale getirilmesiyle enerji üretmek adına biogaz yakılır. Daha sonrasında CHP'den çıkan egzoz gazları ORC ile incelenebilir [27,28]. .Biogaz eldesi sonrasında çürütülmüş olan çamur öncelikle çamur depo 
tankına ardından da santrifüj makinelerine (Dekantör) gelir. Dekantörde susuzlaştırma işlemi ardından da vidalı konveyör vasıtası ile traktöre alınıp depo sahasına taşınır.

\section{ARITMA TESISİ GENEL PARAMETRELERINNE ÖRNEK BAKIŞ}

Bu çalışmada enerji tüketiminin belirlenmesinde örnek olması açısından Adana Ceyhan Atıksu arıtma tesisinde yıllık bakış açısıyla alınan değerlerden tesisin giriş çıkış su debileri, çamur miktarları, üretilen gaz ve enerji miktarları esas alınmıştır. Tesis için gereken enerji, tesisteki jeneratörün ürettiği enerji ve şebekeden çekilen enerji miktarları ölçülerek gerekli olan enerji hesaplamaları yapılmaktadır. Adana Ceyhan Atıksu arıtma tesisinde 1 yıl süresince her ay tesis girişinde ki ve çıkışında ki günlük debi, AAT ndeki mekanik arıtma birimlerinde, biyolojik arıtma birimlerinde, diğer birimler ve AAT tamamı için toplam enerji kullanımı ve AAT ait tasarım argümanları elde edilmiştir. Bu verilere dayanarak, AAT girişteki yükleri, enerji ilişkileri, şebekeden çekilen enerji, giderim verimleri, jeneratör enerji üretimi incelenerek toplam enerji tüketimi açısından $\mathrm{kWh} / \mathrm{m} 3$ cinsinden arıtım enerji miktarları, m3/kişi ve harcanan enerji/kişi miktarları bulunmuştur. Tablo1.'de Ceyhan AAT 2017 yılına ait verilerin aylık bazda çamur değerleri verilmiştir, Tablo2.'de de Ceyhan AAT nin 2017 yılı süresince takip edilen enerji değerleri verilmiştir.

Tablo 1. Ceyhan AAT Yıllık Çamur Parametreleri(2017)

\begin{tabular}{|c|c|c|c|c|c|c|c|c|}
\hline \multirow{2}{*}{ Aylar } & \multirow[t]{2}{*}{ Debi } & $\begin{array}{c}\text { Nihayi } \\
\text { Çamurkeki } \\
\text { Miktarı }\end{array}$ & $\begin{array}{c}\text { Kullanılan } \\
\text { Polimer } \\
\text { miktarı }\end{array}$ & \multicolumn{3}{|c|}{$\begin{array}{c}\text { Dekantör Kuruluk } \\
\%\end{array}$} & $\begin{array}{c}\text { Gaz } \\
\text { Miktarı } \\
\text { (Üretilen) }\end{array}$ & \multirow{2}{*}{$\begin{array}{c}\text { Çakmakta } \\
\text { Yakılan } \\
\text { Gaz } \\
\text { Miktarı } \\
\mathbf{N m}^{3} / \mathbf{a y} \\
\end{array}$} \\
\hline & & $\mathrm{m}^{3} / \mathbf{a y}$ & kg/ay & & talama & & $\mathrm{Nm}^{3} / \mathrm{ay}$ & \\
\hline Ocak & $1.049 .660,00$ & 528,46 & 1383,2 & 25,49 & 25,99 & 26,05 & $48.550,00$ & 0,00 \\
\hline Şubat & $916.951,00$ & 497,16 & 1253,2 & 25,40 & 25,54 & 25,46 & $42.840,00$ & 506 \\
\hline Mart & $973.550,00$ & 510,98 & 1417,45 & 25,34 & 25,47 & 25,65 & $47.550,00$ & 280 \\
\hline Nisan & $863.321,00$ & 538,26 & 1120,05 & 25,94 & 25,98 & 26,05 & $28.590,00$ & 0 \\
\hline Mayıs & 1034123 & 800,18 & 1150,2 & 25,77 & 26,42 & 26,09 & $30.075,00$ & 0 \\
\hline Haziran & $932.447,00$ & 931,65 & 1237,05 & 25,96 & 26,33 & 26,20 & $35.394,00$ & 0 \\
\hline Temmuz & $1.031 .175,00$ & 670,46 & 1188,9 & 25,79 & 25,80 & 25,96 & $36.609,00$ & 0 \\
\hline Ăgustos & $834.529,00$ & 381,60 & 827,1 & 25,62 & 25,81 & 25,86 & $22.213,00$ & 0 \\
\hline Eylül & $842.349,00$ & 360,36 & 840,9 & 26,28 & 25,96 & 25,78 & $22.016,00$ & 0 \\
\hline Ekim & $729.106,00$ & 309,60 & 733,5 & 25,59 & 25,43 & 25,69 & $24.346,00$ & 0 \\
\hline Kasım & $874.709,00$ & 533,57 & 1102,3 & 25,52 & 25,69 & 25,36 & $29.844,00$ & 0 \\
\hline Aralık & $974.030,00$ & 491,50 & 1435,05 & 25,47 & 25,21 & 25,58 & $40.531,00$ & 0 \\
\hline Ortalama & $921.329,17$ & 546,15 & $1.140,74$ & 25,68 & 25,80 & 25,81 & $34.046,50$ & 65,50 \\
\hline Toplam & $11.055 .950,00$ & $6.553,83$ & $13.688,90$ & & & & $408.558,00$ & 786,00 \\
\hline
\end{tabular}

Ceyhan AAT nde yıllık ortalama 546,15 m3 çamur keki çıkarken; yıllık ortalama 34046,50 m3'te gaz üretilmektedir. Yine tesiste yıllık periyotta toplam 6553,83 m3çamur keki çıkarken yıllık toplam $408.558 \mathrm{~m} 3$ 'te gaz üretilmektedir. Ceyhan'da yayla ve deniz turizminin çok olması sebebiyle yaz aylarında polimer miktarı 827,1 kg/ay kadar düşmektedir. Yaz aylarında tesise giren debiye de bakıldığı zaman Temmuz ayında olağan dışı bir artış görülmekte. Bu artışın sebebi 2017 yılının haziran ayı sonunda Ramazan Bayramının olması ve bayram sonunda da bu yoğunluğun devam etmesiyle debi girişinin artmış oluşudur. Bir önemli noktaya daha değinmek gerekirse kullanılan polimer miktarı debi ile bağlantılı olmakla birlikte asıl önemli olan skala çamurun yoğunluk derecesidir. Bu sebeple mevsimsel olarak belirli bir ortalama olmuş olsa da polimer miktarının bazı aylarda dikkat çekici şekilde farklı oluşu çamur yoğunluğu ile alakalıdır. Ceyhan AAT lerinde elde edilen 2017 yıllık enerji değerleri Tablo 2‘de verilmiştir.

Tablo 2. Ceyhan AAT lerinde Elde Edilen 2017 Yıllık Enerji Değerleri

\begin{tabular}{cccccc}
\hline \multirow{3}{*}{ Aylar } & \multirow{2}{*}{ Debi } & Jeneratör & $\begin{array}{c}\text { Şebekeden Alınan } \\
\text { E. }\end{array}$ & $\begin{array}{c}\text { Toplam } \\
\text { E.Tüketimi }\end{array}$ & $\begin{array}{c}\text { E.Geri } \\
\text { Kazanımı }\end{array}$ \\
\cline { 2 - 6 } & & E. Üretimi & $\mathbf{( k W h / a y )}$ & $\mathbf{( k W h / a y )}$ & $\mathbf{( \% )}$ \\
\hline \multirow{2}{*}{ Ocak } & $\mathbf{m}^{\mathbf{3} / \mathbf{a y}}$ & $\mathbf{( k W h / a y )}$ & & & \\
\hline
\end{tabular}




\begin{tabular}{cccccc}
\hline Şubat & $916.951,00$ & $75.714,51$ & $65.768,22$ & $141.482,73$ & 53,67 \\
\hline Mart & $973.550,00$ & $88.936,64$ & $73.998,88$ & $162.935,52$ & 54,41 \\
\hline Nisan & $863.321,00$ & 54.039 & $90.833,4$ & $144.872,40$ & 37,44 \\
\hline Mayıs & 1034123 & 56.042 & $94.783,5$ & $150.825,50$ & 37,38 \\
\hline Haziran & $932.447,00$ & $63.526,07$ & $100.056,6$ & $163.582,67$ & 38,91 \\
\hline Temmuz & $1.031 .175,00$ & $62.769,47$ & $11.2738,5$ & $175.507,97$ & 35,95 \\
\hline Ăgustos & $834.529,00$ & 37.543 & $10.9941,3$ & $147.484,30$ & 25,45 \\
\hline Eylül & $842.349,00$ & 37.090 & $118.918,8$ & $156.008,80$ & 23,93 \\
\hline Ekim & $729.106,00$ & 42.086 & $92.723,4$ & $134.809,40$ & 31,76 \\
\hline Kasım & $874.709,00$ & 52.194 & $98.539,62$ & $150.733,62$ & 34,97 \\
\hline Aralık & $974.030,00$ & 72.908 & $99.243,9$ & $172.151,90$ & 42,63 \\
\hline Ortalama & $921.329,17$ & $60.554,46$ & $94.693,89$ & $155.248,36$ & 39,01 \\
\hline Toplam & $11.055 .950,00$ & $726.653,52$ & $1.136 .326,71$ & $1.862 .980,29$ & \\
\hline
\end{tabular}

Ceyhan AAT nden y1llk ortalama 155248,36 kWh enerji tüketilirken; bunun ortalama 60.554,46 kwh'1 gaz jeneratöründen üretilmektedir. Yine tesiste y1llık periyotta toplam $1.862 .980,29 \mathrm{kWh}$ enerji tüketilirken; bu enerjinin 726.653,52 kwh'1 gaz jeneratöründen üretilmektedir.

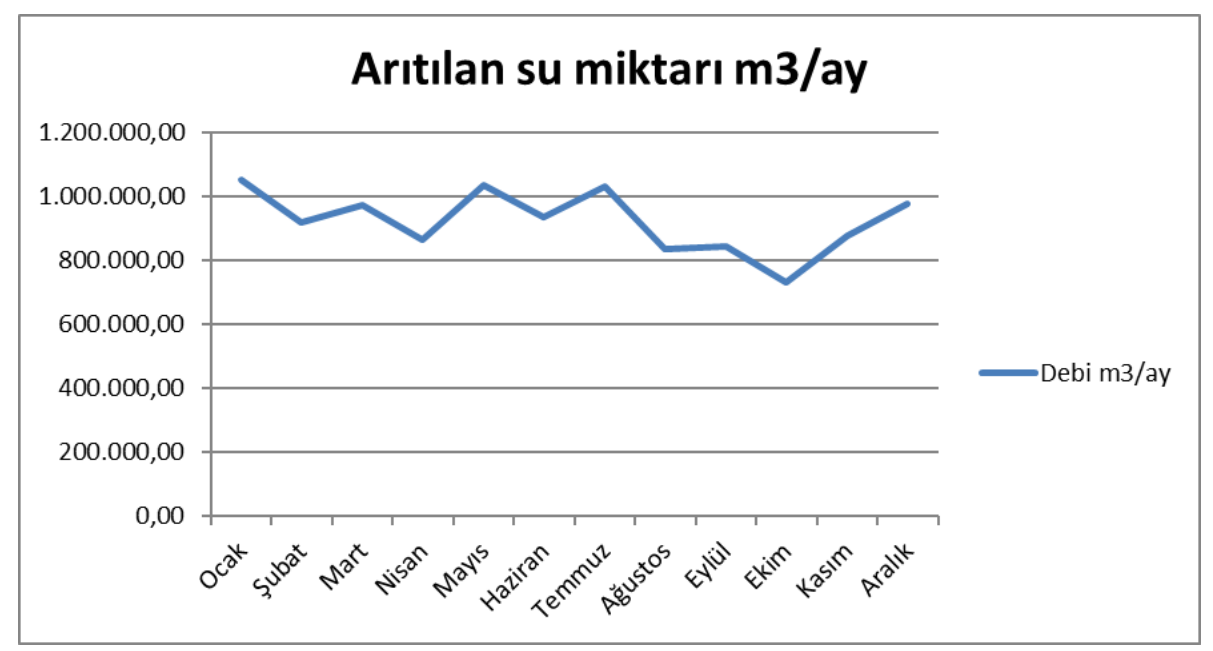

Şekil 2. Ceyhan AAT Aylık Arıtılan Atıksu Verileri (2017)

Ceyhan Atıksu Arıtma Tesisine ait; Şekil 2. de, görüldüğü gibi 2017 yılı aylık arıtılan atık su verilerinden en yüksek debinin 1.049.660,00 m3/ay ile Ocak ayı olurken en düşük debi ise 729.106,00 m3/ay Ekim ayıdır. Şekil 3'de ise enerji değerleri verilmiştir.

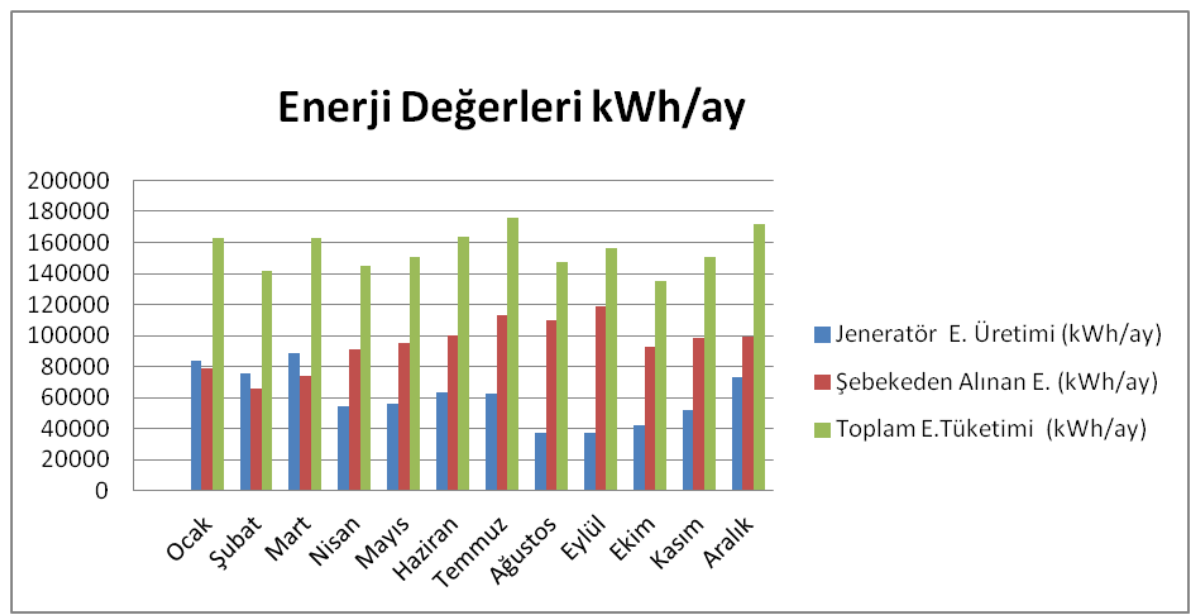

Şekil 3. Ceyhan AAT Ayllk Enerji Verileri (2017) 
Ceyhan Atıksu Arıtma Tesisine ait; Şekil 3. de, görüldüğü gibi 2017 yılı aylık enerji değerleri verilerinden en yüksek enerji üretiminin 88.936,64 kwh/ay ile Mart ayında olduğu anlaşılmaktadır. Şekil 4'de ise enerji geri kazanımının yüzdesi verilmiştir.

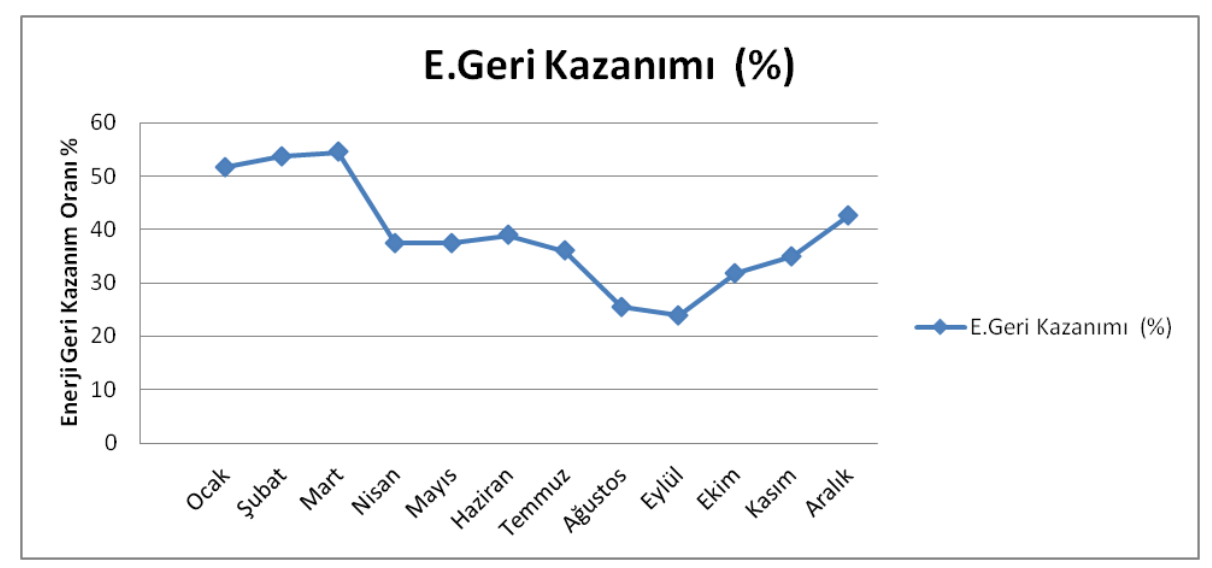

Şekil 4. Ceyhan AAT Aylık Enerji Geri Kazanım Verileri (2017)

Ceyhan Atıksu Arıtma Tesisine ait; Şekil 4. te, görüldüğü gibi 2017 y1lı aylık enerji değerleri geri kazanımı verilerinden en yüksek kazanımın \%54,41 ile Mart ayında olduğu anlaşılmaktadır. Şekil 5'de m3 başına harcanan enerji miktarı verilmişstir.

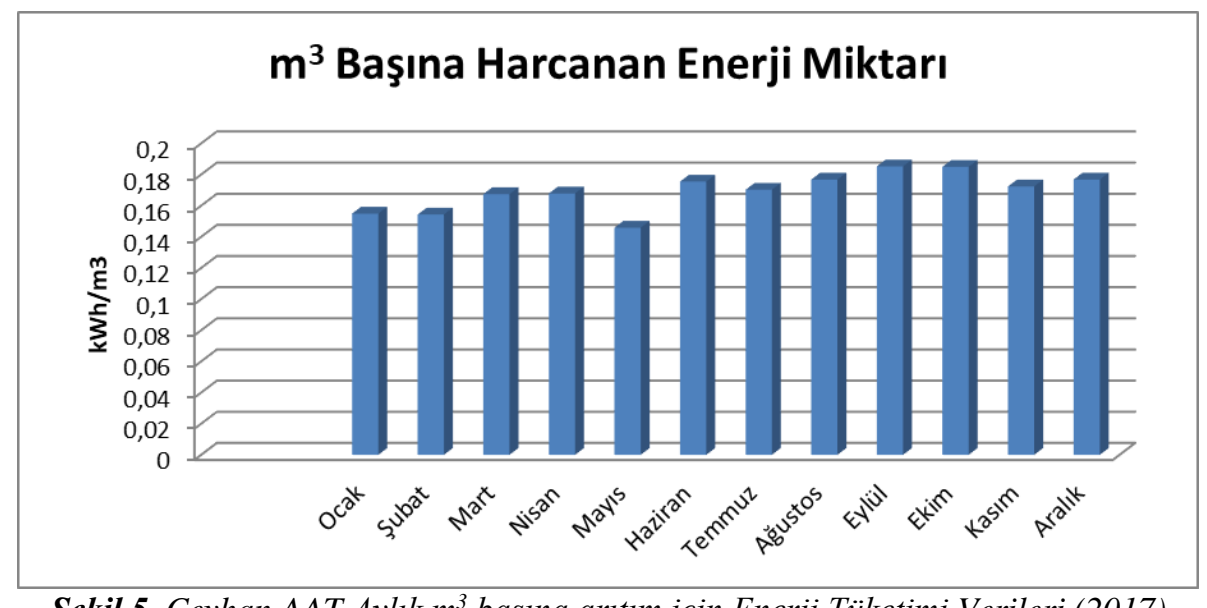

Şekil 5. Ceyhan AAT Aylık $\mathrm{m}^{3}$ başına arıtım için Enerji Tüketimi Verileri (2017)

Ceyhan Atıksu Arıtma Tesisine ait; Şekil 5. te, görüldüğü gibi 2017 yılı atıksu arıtımı aylık m3 başına harcanan kWh enerji değerleri en az 0,14 ile Mayıs ayında olduğu anlaşılmaktadır. Şekil 6'da üretilen gaz ile arıtılan suyun kıyaslama verileri gösterilmiştir. 


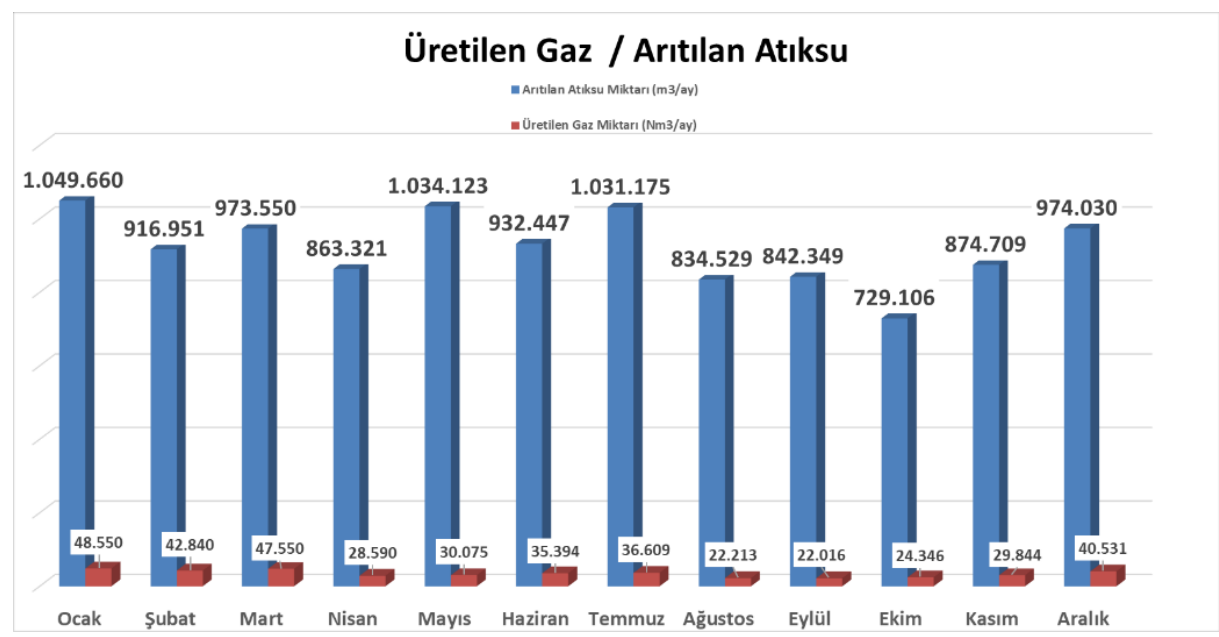

Şekil 6. Ceyhan AAT Aylık Arıtılan Atıksu Miktarı Üretilen Gaz İlişkisi (2017)

Ceyhan Atıksu Arıtma Tesisine ait; Şekil 5. te, görüldüğü gibi 2017 yılı aylarında arıtılan su miktarı ve üretilen gaz miktarının sırasıyla 1.049.660,00 m3/ay ve 48.550,00 m3/ay ile Ocak ayında en yüksek seviyede olduğu anlaşılmaktadır. Ağustos ayında arıtılan su miktarı 834,529 m3/ay Üretilen gaz miktarının ise 22,213 m3/ay olması Ceyhan da yayla ve deniz turizmin çok olmasından dolayı yaz aylarında nüfusun azalmasından kaynaklanmaktadır. Şekil 7'de çıkan çamur keki ile kullanılan polimer oranı verilmiştir.

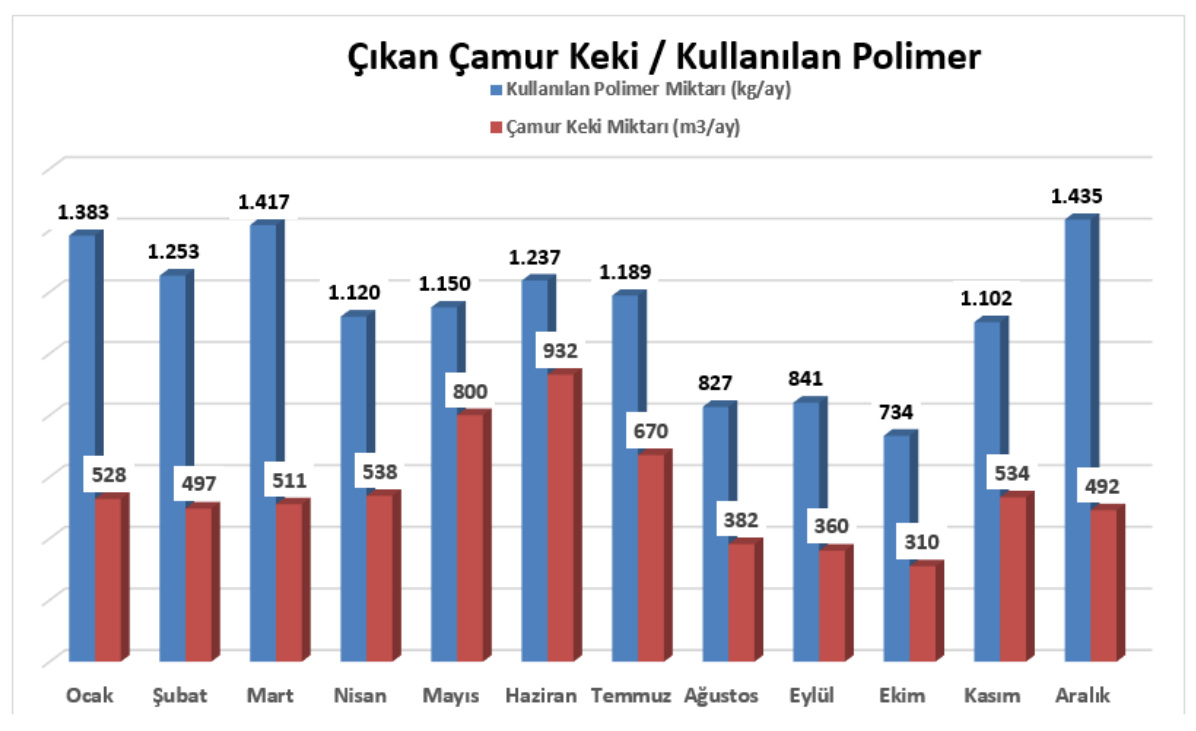

Şekil 7. Ceyhan Atıksu Arıtma Tesisi 2017 Yılı Aylık Çıkan Çamur Keki-Kullanılan Polimer İlişkisi

Ceyhan Atıksu Arıtma Tesisine ait; Şekil 7. de, görüldüğü gibi 2017 yılı aylık çıkan çamur keki ve kullanılan polimer miktarları sırasıyla 309,6 m3/ay ve 733,5 kg/ay ile Ekim ayında en düşük seviyede olduğu anlaşılmaktadır. Bunun en önemli sebebi ölçülen çamur yoğunlukları neticesinde polimer ihtiyacının bu denli yeterli oluşu ve prosesi kurtarışıdır. Şekil 8'de üretilen gaz ile jeneratör üretimi oranı verilmiştir. 


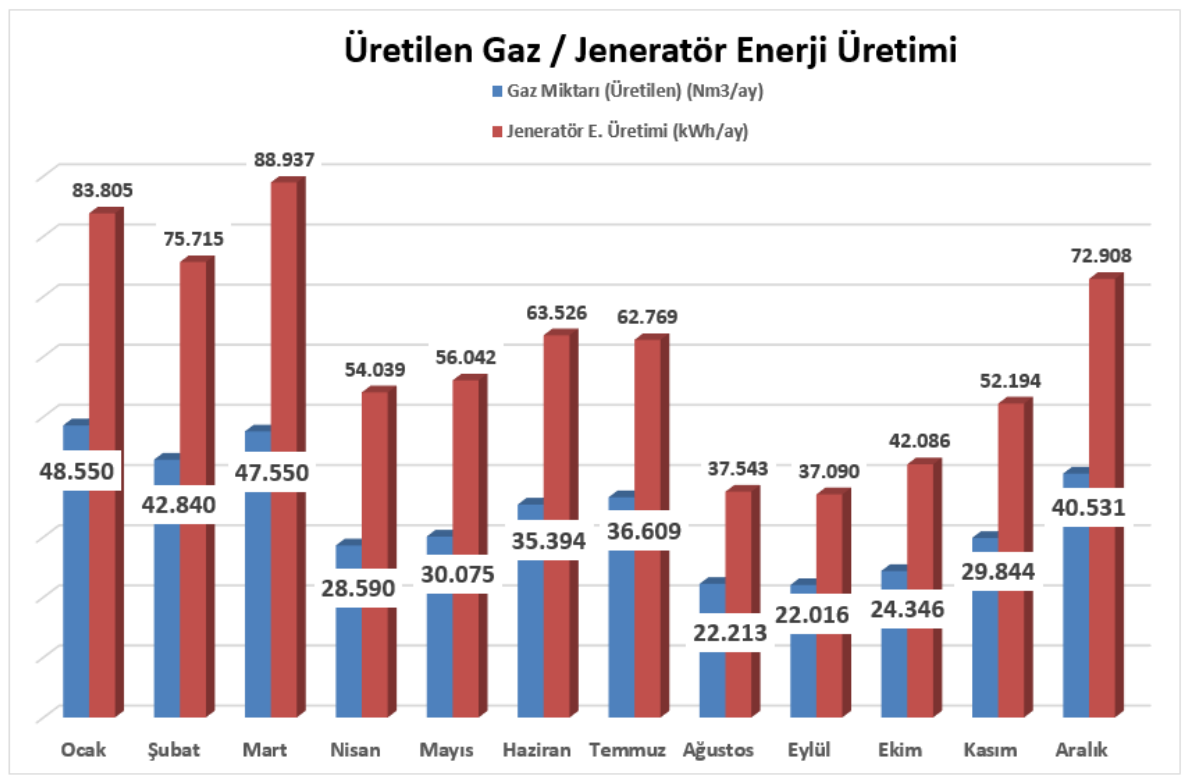

Şekil 8.Ceyhan Üretilen Gaz Miktarı-jeneratör enerji üretim ilişkisi(2017)

Ceyhan Atıksu Arıtma Tesisine ait; Şekil 7. de, görüldüğü gibi 2017 yılı aylık üretilen gaz ve jeneratörün enerji üretim miktarları sirasıyla 48550,00 m3/ay ile Ocak ayında ve 88936,64 kwh/ay ile Mart ayında en yüksek seviyede olduğu anlaşılmaktadır. Bunun en önemli sebebi kış aylarında Ceyhan da nüfusun yoğun olmasından kaynaklanmaktadır. Şekilde de görüldüğü gibi Ceyhan da yayla ve deniz turizmin çok olmasından dolayı yaz aylarında nüfusun azalmasından dolayı üretilen gaz ve jeneratörün enerji üretiminin de azalmasından kaynaklanmaktadır.

\section{SONUÇLAR}

Atıksu arıtma tesislerinde uygulanan arıtma prosesleri sonucu nihai ürün olarak fazla miktarda arıtma çamuru meydana gelmektedir. Arıtma çamurlarının bertarafı genelde çamurun susuzlaştırılarak hacminin azaltılması, depolama ünitelerine taşınması ile yapılabilir iken kullanılan yöntem ekstradan bir mali yük ile beraber boş alan işgaline sebep olması bakımından istenmeyen bir durumdur. Ayrıca vahşi depolama alanları da çevre için büyük oranda risk taşımaktadır. Atıksuların çevreye vermesi muhtemel zararlı etkilerinin ortadan kaldırılması gerekmektedir. Atıksuların arıtımından geriye kalan artık maddeler, genelde 1zgaralardan çıkan çöp, kum, biyolojik ve kimyasal işlemler sonucunda ortaya çıkan çökebilir ve yüzdürülebilir katı maddelerdir. Bugün Dünyada mevcut çamur uzaklaştırma yöntemlerinin önümüzdeki yıllarda, çamur artışından kaynaklanan problemlerin çözümünde yeterli olamayacağı düşünülmekte olup yeni yöntem ve teknolojilerin geliştirilmesi gündeme gelmiştir. Dünyada çamur uzaklaştırma yöntemleri çamurların ziraatta-toprakta kullanılması, çamurun toprağın niteliğini iyileştirmesi, ürünün verimi ve kalitesinin artırımı açısından ekolojik bir adım olarak görülmektedir. Çamur susuzlaştırma ünitelerinden çıkan çamurun bertaraf edilme zorluğu ve ekonomisi çamur yönetiminde daha yüksek kuru madde miktarının elde edilmesi açısından önem arz etmektedir. Atıksu arıtma tesisten çıkan çamurun kurutulup, yakılarak hem bertaraf edilmesi hem de çıkan 1sı ile elektrik üretecek sistemlerin yaygınlaşmasıyla; arıtma tesislerinden günlük tonlarca çamur çıktığı ve bu çamurun da kurutulup yakıldıktan sonra geriye kalan kısmın da neredeyse tamamının bertaraf edilebileceği, gelecekte yapılacak çalışmalar açısından umut veren bir bilgidir. Adana Ceyhan Atıksu Arıtma tesisi, yıllık periyotta incelendiğinde elde edilen değerler doğrultusunda; Adana Ceyhan Atıksu arıtma tesisi aktif çamur tesisidir. Bu tür tesislerde yüksek enerji ve işletme giderleri ile bilinmektedir. Düşük hacimlerde aşırı debiyi karşılayabilen bu sistem Ceyhan Atıksu arıtma tesisi için elverişli olduğu hesaplanmıştır. Atıksu arıtma tesisi tespit edilen araştırma neticeleri sonucunda; Atıksu arıtma tesisi genelinde arıtma verimleri, 2017 yılında en yüksek verim \% 54,41 ile Mart ayıdır. Yıllık ortalama ise \% 39,008'dir.

Kış aylarında Ceyhan da nüfusun yoğun olmasından dolayı gaz üretimi ve polimer tüketimi yüksek değerlerdedir. Yaz aylarında ise Ceyhan halkının yayla ve deniz turizmine ilgi duyması neticesinde nüfusun azalmasıyla üretilen gaz azalmaktadır, dolayısıyla jeneratörden elde edilen enerji üretiminde azalmasına neden olmaktadır.

$\mathrm{Bu}$ çalışma enerji verimliliği temelinde kentsel Atıksu arıtma tesisi yatırımların sürdürülebilirliğinin belirli bir standarda göre sağlanması açısından da önem arz etmektedir.

\section{KAYNAKLAR}

[1] Buonocore, E., Mellino, S., De Angelis, G., Liu, G., \& Ulgiati, S. (2018). Life cycle assessment indicators of urban wastewater and sewage sludge treatment. Ecological indicators, 94, 13-23. 
[2] Molinos-Senante, M., Sala-Garrido, R., \& Iftimi, A. (2018). Energy intensity modeling for wastewater treatment technologies. Science of the Total Environment, 630, 1565-1572.

[3] Özyazıcı M A, Özyazıcı G (2012). Arıtma Çamurunun Toprağın Bazı Temel Verimlilik Parametreleri Üzerine Etkileri. Anadolu Tarım Bilim Dergisi, 27(2): 101-109.

[4] Rojas, J., \& Zhelev, T. (2012). Energy efficiency optimisation of wastewater treatment: Study of ATAD. Computers \& Chemical Engineering, 38, 52-63

[5] WERF. (2011). Energy Management. Alexandria, VA: Water Environment Research Foundation.

[6] Koç, A., Yağl1, H., Koç, Y., \& Uğurlu, İ. (2018). dünyada ve türkiye’de enerji görünümünün genel değerlendirilmesi. Mühendis ve Makina, 59(692), 86-114.

[7] Atıksu Arıtma Tesisi Çamurlarının Değişik Amaçlarla Kullanımının Araştırılması. Doktora Tezi, İstanbul Üniversitesi Fen Bilimleri Enstitüsü, İstanbul.

[8] Gomez, A., Bernal, M.P. and ROIG, A., (2002). Growth of Ornamental Plants in Two Composts Prepared from Agroindustrial Wastes. Biores.Technol. 83, 81-87.

[9] Logan, B. E. (2005). Simultaneous wastewater treatment and biplogical electricity generation. Water Science and Technology, 52 (1-2), 31-37.

[10] İRDEMEZ, Ş., YILMAZ, A. E., \& ANLATICI, E. Evsel Atıksu Arıtma Çamurlarının Termal Kurutma-Yakma Prosesi ile Uzaklaştırılmasında Arıtma Verimi-Enerji İlişkisinin İncelenmesi. Iğdır Üniversitesi Fen Bilimleri Enstitüsü Dergisi, 6(4), 65-73.

[11] Lee, K. M., Griffith, P., Farrell, J. B., \& Eralp, A. E. (1987). Conversion of municipal sludge to oil. Journal (Water Pollution Control Federation), 884-889.

[12] http://www.osbuk.org/atiksu.aspleri, R., 2000. Çevre Biyoteknolojisi. Değişim Yayınları, Adapazarı.

[13] Liu, Y., Li, J., Guo, W., Ngo, H. H., Hu, J., \& Gao, M. T. (2018). Use of magnetic powder to effectively improve the performance of sequencing batch reactors (SBRs) in municipal wastewater treatment. Bioresource technology, 248, 135-139.

[14] Tchobanoglous, G., Burton, F. L., \& Stensel, H. D. (1991). Wastewater engineering. Management, 7, 1-4.

[15] Arceivala, S. J. (1981). Wastewater treatment and disposal: engineering and ecology in pollution control.

[16] Gazete, R. (2004). Su Kirliliği Kontrolü Yönetmeliği. TC Çevre ve Şehircilik Bakanlığı, Karar, 8289.

[17] YAĞLI, H., \& Yıldız, K. O. Ç. Hayvan Gübresinden Biyogaz Üretim Potansiyelinin Belirlenmesi: Adana İli Örnek Hesaplama. Çukurova Üniversitesi Mühendislik-Mimarlık Fakültesi Dergisi, 34(3), 35-48.

[18] Spinoza, L. ve Vesilind P.A., 2001. Sludge into Biosolids: Processing, Disposal and Utilization, IWA Publishing, United Kingdom.

[19] Ünlü, A. ve Tunç, M.S.,2007.Elazığ kenti atıksu arıtma tesisi çamur işleme birimlerininişletiminin değerlendirilmesi. Firat Ü.Fen ve Mühendislik Bilimi Dergisi, 19(1), 53-60.

[20] OSBÜK-Atıksu, 2007. Atiksu arıtımının esasları, Organize Sanayi Bölgesi Üst Kurulusu resmi web sitesi, Eylül 2007

[21] Filibeli, A. (1998) Arıtma çamurlarının işlenmesi, Dokuz Eylül Üniversitesi Yayınları No:225, ISBN 975-441-117-4, 1-25 / 71-100

[22] Tchobanoglous, G., Burton, F.L. and Stensel, H.D., 2003. Wastewater Engineering: Treatment and Reuse, Mc Graw Hill Press, New York U.S.

[23] Sopper, W.E., 1989. Utilisation of Sewage Sludge in the United States for Mine and

Reclamation. Alternative Uses for Sewage Sludge Conference Proceedings.U.K. 5-7 September 1989, 21-40.

[24] Palabıyık, H., Çevre Sorunu Olarak Kentsel Katı Atıklar (Çöpler) ve Entegre Katı Atık Yönetimi, Türk İdare Dergisi, 70(420):45-64,1998, Ankara.

[25] Aksu, T, (2008). Isparta Belediyesi Atık Su Arıtma Tesisinde Oluşan Çamurun Bertaraf Stratejilerinin Araştırılması, Süleyman Demirel Üniversitesi Fen Bilimleri Enstitüsü Yüksek Lisans Tezi, 2008

[26] Boztoprak, H. (2014). Görüntü işleme teknikleri ve yapay zeka yöntemleri kullanarak atık su arıtmada performans analizlerinin incelenmesi (Doctoral dissertation, Selçuk Üniversitesi Fen Bilimleri Enstitüsü).

[27] Parametric optimization and exergetic analysis comparison of subcritical and supercritical organic Rankine cycle (ORC) for biogas fuelled combined heat and power (CHP) engine exhaust gas waste heat.

[28] Koç, Y., Yağlı, H., \& Koç, A. (2019). Exergy analysis and performance improvement of a subcritical/supercritical organic rankine cycle (ORC) for exhaust gas waste heat recovery in a biogas fuelled combined heat and power (CHP) engine through the use of regeneration. Energies, 12(4), 575. 